\title{
ЛІНГВОПОЕТИЧНА РЕПРЕЗЕНТАЦІЯ КОНЦЕПТУ МАТИ
}

Колоїз Ж. В. Лінгвопоетична репрезентація концепту МАТИ.

У статті йдеться про особливості репрезентації концепту МАТИ у віршованих текстах; акцентовано передусім на дослідженні перцептивних образів, що грунтуються на відчуттях; проаналізовано візуальні, тактильні, одоративні, аудіальні чуттєві образи, їхню вербалізацію; маніфестовано смислове наповнення досліджуваного концепту; проілюстровано його здатність вступати в різні асоціативні зв'язки.

Ключові слова: концепт, чуттєвий образ, художній образ, смислове наповнення, асоціативні зв'язки.

Колоиз Ж. В. Лингвопоэтическая репрезентация концепта $М A T Ь$.

В статье исследуются особенности репрезентации концепта МАTЬ в стихотворных текстах; акцентируется внимание прежде всего на исследовании перцептивных образов, основанных на чувствах; анализируются визуальные, тактильные, одоративные, аудиальные чувственные образы, их вербализация; выявляется смысловое наполнение исследуемого концепта; иллюстрируется его способность вступать в разные ассоциативные связи.

Ключевые слова: концепт, чувственный образ, художественный образ, смысловое наполнение, ассоциативные связи.

Kolojiz Zh. V. Linguopoetic presentation of concept MOTHER.

The article deals with peculiarities of presentation of concept MOTHER in the poetry. It is emphasized on the search of perceptive images, which is based on feelings. Visual, tactile, olfactory, aural feeling images and their verbalization are analyzed. The meaning filling and associative connections of searched concept are presented and illustrated.

Key words: concept, feeling image, poetic image, meaning filling, associative connections.

3’ясування сутності концепту, його структури, причин виникнення, вербалізації, репрезентації і т. ін. і надалі залишається досить актуальною проблемою, про що свідчить збагачення відповідного наукового простору солідними науковими доробками та видатними іменами, як-от: 
М. Алефіренко, М. Болдирев, С. Воркачев, К. Голобородько, В. Карасик, О. Кубрякова, Л. Лисиченко, В. Маслова, Т. Матвєєва, М. Нікітін, М. Полюжин, 3. Попова, А. Приходько, О. Селіванова, Ю. Степанов, Й. Стернін та багато інших. Щоправда, попри розмаїття так званих концептологічних праць, оформлених у вигляді монографій, посібників, словників, статей, одне з основних понять когнітивної лінгвістики (чи то її окремої царини - концептологіï) так i не отримало одностайного витлумачення [1, с. 31-45]. Натомість сучасний стан концептологічної теорії окреслює нові перспективи дослідження мовомисленнєвих процесів, спонукає до грунтовного дослідження концептуальних систем тієї чи тієї мови на різних етапах іiі розвитку, різних стилів або структурно-смислових площин окремих концептів, зокрема й тих, які отримали кваліфікацію універсальних [9, с. 89; 10, с. 120].

Одним із таких універсальних, найбільш значущих, наявних у всіх культурах, основних у концептосфері та національній свідомості їх носіїв, $\epsilon$ концепт МАТИ, що так само неодноразово ставав об'єктом зацікавлення як зарубіжних, так і вітчизняних мовознавців (М. Андреянова, С. Бартіш, Є. Гороть, А. Кербс, М. Кононенко, О. Кострубина, Ж. Марфіна, У. Марчук, А. Пікалова).

Не викликає жодних спростувань те, що цей концепт має давню історію, репрезентує великий обсяг знань та інформації, нагромаджений носіями тієї чи тієї лінгвоспільноти. Водночас у різних лінгвокультурах фокусування та членування відповідного концептуального простору відбувається по-різному. До того ж концепти мають здатність, так би мовити, розростатися й збагачуватися внаслідок індивідуального досвіду окремих представників національної культури, творчих особистостей, до яких належать передусім письменники. У художньому просторі, як відомо, концепт $є$ «результатом уяви митця, який конструює нову реальність відповідно до індивідуального світобачення, внутрішніх інтенцій» [1, с. 49], «відбиває особливості світосприйняття та психології автора і відтворює індивідуальне мовомислення носія концептуальної системи» [1, с. 50]. Інакше кажучи, сформовані впродовж багатьох віків ціннісні орієнтири національної культури доповнюються письменницькими естетичними поглядами, ідеалами, морально-етичними вподобаннями, що розширює спектр уявлень про те чи те явище, дає змогу будувати нові семантичні парадигми. Наприклад: Вони дуже старі. Їхнє сонще не з нашої ери. Його зморики поткали стонадиять полків павуків. І згорають на попіл Танасини, Горпини, Ликери - Чорні птиџі нудьги у скажених мартенах років. Гей віків та віків прокопитило карі навали, Їхні печі впилися - алкогольний вогонь затуха... Вони ж десь позавчора може, мамонтів ще годували 3 свого сивого рубчикового фартуха. Їхня доля горбата столи ӥм щедротно накрилаРік гарматний підрубував вік моровий. Журавлі ӥхню юність завдали собі ๑ ж. В. Колоїз, 2013. 
тяжко на крила, Десь розсипали в Африці в чорні голодні рови. А вони ж нас чекають у якомусь тупому завзятті, Ніби завше на нас недорід, недорід, недорід! Їхні діти найкращі - цибаті, горбаті, рогаті, Темні бевзі і генї наш людський пересмиканий рід. А коли між ракетами пройде батюшка передостанній, Помахає кадилом у кратер затятих смертей - Вони в трунах повстануть, щуоб зітліти в німому чеканні Та в землі виглядати своїх проклятущчи дітей. Вони дуже старі. Їхнє сонще не з нашої ери. Його зморики поткали стонадцять полків павуків. I згорають на попіл Танасини, Горпини, Ликери - Сиві птиці чекання в скажених мартенах років... (I. Драч «Матері́»), де вербалізація концепту МАТИ демонструє співвідношення результату колективного досвіду й широкого спектру авторських уявлень (пор.: Танасини, Горпини, Ликери - узагальнений художній образ матерів, порівнюваних із чорними птицями нудьги, сивими птицями чекання і т. ін.). Оригінальне індивідуально-авторське світобачення передбачає несподівані асоціативні зв'язки, подекуди ускладнює їх.

Мета нашої статті полягає в тому, аби дослідити лінгвопоетичну репрезентацію концепту МАТИ в художньому тексті; з'ясувати, які асоціації виникають у результаті зіткнення смислового наповнення актуалізованого концепту 3 концептуальною системою; виявити нові знання про концептуальну картину письменницького світу.

Джерелом дослідження послужили поетичні твори, присв'ячені матері (понад 100 текстів), різних за своєю структурою, жанровими та функціонально-стилістичними особливостями.

Попри те, що лексема МАТИ є полісемантичною, ïi найчастіше пояснюють як «жінка стосовно дитини, яку вона народила». Таке пояснення має чимало ілюстративних підтверджень, зокрема й у віршованих текстах: Дорости до пісні матерів, Що любов, красу свою $i$ вроду Віддають майбутньому народу, Народивши дочок і синів. I, прожсивии стільки літ і днів, Скільки доля відвела на світі, Не постати в бронзі чи граніті - Залишитись в nісні матерів (М. Луків «Дорости до пісні матерів...»). Утім, таке витлумачення є досить спрощеним, оскільки акцентує лише на біологічному аспекті, залишаючи поза увагою контекст суспільних відносин, соціальні та моральні чинники (скажімо, мати є посередником між зовнішнім світом і дитиною, виховує їі моральні якості, привчає до праці, впливає на формування особистості, сприяє адаптації в соціальному середовищі і т. ін.). Наприклад: Дивлюся на твої долоні, мамо, й читаю наймудріму книгу з книг, щзо в світі изім багато є доріг, а вибрати я з них одну лиш маю. Що рук людських і душ людських чеснота звіряється вагою колоска, щуо завжсд ианувалось у віках одне із найскромніших слів - робота. Що є любов, а ще ненависть є: любов єднає віддалі безмірні, живе єдиним подихом довіри, а на любов ненависть повстає. Що є добро і тінь страшна біди: біду бори, долай круту розпуку, а для добра подай людині руку і яблуню край иляху посади. Іду до тебе, мамо, 
на урок $і$ з слова дізнаюсь неголосного, щуо на землі немає більи святого, ніж сину дати сил на перший крок. Хоч скільки б я доріг пройти устиг чи мозолів нажстти встиг чимало - я до твоїх долонь вертаюсь, мамо, читати наймудріму книгу з книг (В. Баранов «Долоні маминих рук»).

До того ж структура концепту передбачає не тільки інформаційний зміст, згідно з позицією 3. Попової, Й. Стерніна, представлений певними когнітивними ознаками, які визначають основні риси концептуалізованого предмета, але й чуттєвий образ та інтерпретаційне поле [10, с. 82]. Будучи елементом картини світу, відображеної в колективній та індивідуальній свідомості, концепт МАТИ в мові поезій передбачає як об'єктивну інформацію, знання, що існують у вигляді чуттєвих образів, так і ті, які ініційовані уявою письменника. I це цілком закономірно. Адже саме в мистецтві як специфічній формі відображення дійсності створюються художні образи, змодельовані на основі первинних чуттєвих образів, матеріально оформлених за допомогою слів, наявних у системі мови, та ідеї. Твердження про те, що поетична мова образно моделює світ, є неспростовним. У зв’язку з цим В. Калашник зауважує: «У віршовій мові вживане поетом слово трансформується, набуває естетичних якостей і стає конструктивним елементом художнього змісту. При цьому поетичне слово має лише «слабкий ореол зв'язаності з денотативним позамовним простором» $\mathrm{i}$ характеризується наявністю егоцентричних ознак, на яких і грунтується його естетична значущість. Відходячи від стереотипу, митець одухотворяє матеріальне слово практичної мови новою ідеєю і тим самим естетично перетворює його. Слововживання в мові поезії $є$ по суті словоперетворенням, формуванням і виявом поетичної семантики [3, с. 164].

Як свідчить фактичний матеріал, лінгвопоетична репрезентація концепту МАТИ відбувається передусім крізь призму перцептивних (від лат. perceptio - сприйняття) образів, що грунтуються на відчуттях, через які людина отримує інформацію про навколишній світ і які дають ій змогу орієнтуватися в довкіллі.

У мові поезій актуалізуються знання про матір, отримані внаслідок як зовнішніх (рецептори (екстерорецептори) аналізаторів знаходяться на поверхні тіла), так і внутрішніх (рецептори (інтерорецептори) аналізаторів всередині людини) відчуттів. У маніфестації ідеї того чи того художнього твору беруть участь візуальні, або зорові, тактильні, або дотикові, одоративні, або запахові, слухові, або аудіальні, чуттєві образи, грунтовані на різних когнітивних ознаках. У структуру віршованих текстів свідомо вводяться слова відповідної семантики на зразок побачити, почути, відутти. Непоодиноко трапляється в художньому просторі й сама лексема образ, що обов'язково отримує подальшу конкретизацію, деталізацію, як-от: Як тіні вечірні лягали на скло, I я підійшла до віконної рали - Побачила образ високе чоло I брови, і очі, і обриси... мами. Якесь невловиме незриме тепло ๑ ж. В. Колоїз, 2013. 
Війнуло на серие, як ранішній вітер. Ба, навіть холодне обрамлене тло Було теплотою тією зігріте. Сказати словами - та слів тих нема!...Як скучила я... У душі защеміло, Але то не біль, не журба, не пітьма, А щүось сокровенне, таємне і миле. Візьму телефон, наберу, подзвоню... Та ні... турбувати вночі? - для покути Напевне вже пізно... я завтра... по дню... А хочеться так ї̈ голос почути... (К. Ільїна «Мама»).

Найчисельнішими, за нашими спостереженнями, є когнітивні ознаки, засвідчені в образній структурі досліджуваного концепту, які усвідомлені людиною й виокремлені в результаті сприйняття зором. Наприклад: $B$ xami сонячний промінь косо На долівку ляга з вікна... Твої чорні шовкові коси Припорошила вже сивина. Легкі зморшки обличчя вкрили - Це життя трудового плід. Але в кожному русі -сила. В очах юності видно слід. Я таку тебе завжди бачу, Образ в сериі такий несу - Материнську любов гарячу I твоєї душі красу (В. Симоненко «Матері»); Стойть переді мною мати, Така, як бачив я малим. Сміються очі, мов блавати, Крізь жита молодого дим. Сорочка світить, як пелюстка Із ивіту яблуні. Чоло Затінюе зелена хустка, Як птиці райдужне крило. Горить коралове намисто, Талярів міниться луска, А сонще сяє й пахне чисто, Немов дійниия молока (Д. Павличко «Стоїть переді мною мати...»); Там, де лягло Чорномор'я без меж В білому осені злоті, - Ти, моя мати, обніжком ідеш, Рідна, висока в скорботі. Як ти пройшла із безхмарним чолом Боса - по стернях і росах? Де ти лежиш у траві за селом В тихих вишневих Глодосах? Скільки за вік ти зв'язала снопів, Скільки посіяла жита! Нині лежсии ти в мовчанні степів, Небом холодним укрита. Ось я в далекі поӥхав краї, - Й тут серед темної ночі Сняться натруджені руки твої, Сині зажурені очі; Наче я знов на гарячих снопах Плачу під спів жайворінка... Тихо проходить в херсонських cтепах Мати моя українка (Т. Масенко «Там, де лягло Чорномор'я без меж...»). Примітним $є$ те, що митці акцентують перш за все на характеристиках (загальних і часткових) зовнішності: материнські - постава, постать, обличчя, усмішка, чоло, брови, очі, руки. Звідси, відповідно, прикметники, утворені від іменників мати (мама), досить часто функціонують як поширюючі компоненти. Очевидно, закономірним є й те, що в портретних

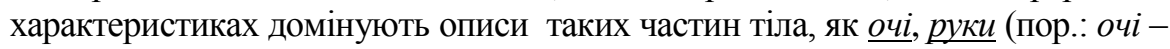
дзеркало душі, а руки є свідченням перейдених років, пережитих труднощів). Епітети, що супроводжують названі лексеми, у першому разі акцентують на кольорі і розмірі (великі, світлі, чорні, голубі, сині, карі): Спіть, моя мати, моя кароока, зірка влетіла до хати. Ясно світи, моя зоре висока, Спіть, моя мати. Світиться вогник у нас опівночі, внука йдете колихати. Світять мені ваші яснії очі, спіть, моя мати (М. Сингаївський «Колискова матері»); Не одкриє мати карі очі і не скаже: "Синку, синку мій!» Там, де вишні хиляться й шепочуть, спить вона давно в землі сирій (В. Сосюра «Не одкриє мати карі очі...»); у другому - епітетні супровідники характеризують об'єкт за 
привабливістю / непривабливістю (прекрасні, пречисті, прозорі, висохлі, зашерхлі, старечі): Де мати посіє, там стелиться ласка, Де мати посадить, там сходить добро, Бо в мами рука і легка, і прекрасна, I серие глибоке, як сивий Дніпро (В. Крищенко «Де мати посіє...»); У спогадів на дні, як в зяючому кратері, Бушує попіл, виє тишина. Я згадую прозорі руки матері. Вона живе. В мені живе вона (М. Бажан «Пролог до спогадів»); Я вже й сам вечорію, А отут, біля вас, мов хлопчисько, стою. Тільки серце моє кревним болем жаріє, Тихо точить синівську зажуру свою. Воно бачить над вали сніжисту хуртечу, Що кружля й покриває життя сіножать. Ваші висохлі, зморені руки старечі, Наче птииі завмерлі, на ліжку лежать. О, якби ваші руки я зміг обігріти У спокуті за все, чим я вам завинив... Але вічного боргу мені не сплатити їм, пречистим, як совість, як суд сивини (В. Кочевський «Мамині руки»).

У деяких поетичних текстах ті чи ті когнітивні ознаки виражаються опосередковано, через стосунок до іншого явища, що потребує додаткових інтерпретативних зусиль з боку адресата: Сліз не треба, ненько, ми вже не маленькі - Вамі соколята, соколи-сини... Хочеться додому, матінко рідненька, Перед ваші очі ранньої весни (М. Дмитренко «Мамине обличчя у дитинство кличе») (пор.: з одного боку, колір ранньої весни - це колір зелені, дерев, кущів, що розпускаються, чи молодої трави, тобто світлозелений; з іншого, - це колір весняного неба, талих вод, тобто голубий і т. ін.). Семантично глибокими є характеристики, маніфестовані через описові конструкції, подекуди й багатокомпонентні, як-от: - Чого так гірко плачеш, мамо, I тиснеш руки до грудей? - Я дуже мало, дуже мало Пізнала ласки від дітей. - Чого так посивіла рано I ув очах - немов пітьма? - Бо діти як болюча рана, А кращих, іншеньких нема (В. Крищенко «Материнський біль») (пор.: пітьла - «відсутність світла, освітлення; темнота, тьма», тобто очі, які потьмарилися від хвилювання, пережитого болю); У маминих очах неначе ивіт лілеї I жар зорі - че бачила не раз. Коли нам гірко - ми приходимо до неї, I забуваємо ї̈ в солодкий час (В. Крищенко «До маминих очей») (пор.: цвіт лілеї, мабуть, ідеться саме про білу, свідчить про чистоту, а жар зорі - про яскравість, ясність, тобто яскраво-чисті очі). Такі зіставлення «рухають» думку, творчу уяву, загострюють художні деталі. Зауважимо: чимало текстів містить актуалізовані лексеми очі, руки в самих назвах художніх творів, у яких спостерігається не лише метонімічне, а й метафоричне перетворення (мати - руки), зорієнтовані на образне

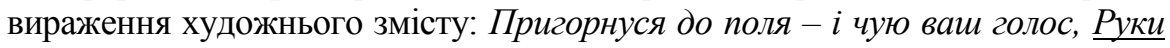
бачу в землі, роботящі колись, Що в колгоспі за довгі літа напололись, На жнивах нав'язалися $і$ напеклись. Вони пестили ніжно $і$ часом карали, Були пристанню долі в годину трудну I мене із гіркими слізьли обнімали, Як вчорашній школяр, я ішов на війну. I коли насували, як тьма, поторочі Й прибережне каміння палало в огні, У тривожних, поранених снах опівночі ๑ ж. В. Колоїз, 2013. 
Bаші руки з-за моря світились мені (В. Кочевський «Мамині руки») (пор.: руки були пристанню долі - місцем, де можна сховатися, відпочити, знайти притулок і т. ін.; пристановищем; руки світилися - захищали; випромінюючи світло, допомагали зорієнтуватися). Варто, мабуть, акцентувати й на тому, що в непоодиноких контекстах простежується взаємодія візуальних і тактильних чуттєвих образів (у мами рука легка і прекрасна). Пор. також: Перегримілий шторм клавіатури, Тачанка, вилетіла на щербатий брук, Обгортка більшовицької брошури, Що взяв, як хліб, ти з материнських рук. Ти кожну синю жилку пальчів бачиш, Ласкавих пальців жовтої руки, Вчуваєш їх нерівний пульс і плачеш, Як плачуть в снах самітні старики (М. Бажан «Пролог до спогадів»).

Досить поширеною характеристикою зовнішності, яка грунтується на зорових відчуттях, є вікова, що зазвичай сприймається через опозицію молода -стара: Якби мені, мамо, сьогодні Дозволили вибирати, Де мені далі жити Й довершувати діла, - Я вибрав би не країну, Палащи а чи палати: Я вибрав би, мамо, дитинство, Де ти молодою була (В. Баранов «Якби мені, мамо, сьогодні...»). Утім, лексема стара (у значенні «про жінку, яка досягла старості») трапляється дуже рідко, здебільшого вона модифікується чи то в інший (похідний) прикметник (старенька), чи то в дієслово (старіти $\rightarrow$ постаріти): Чорнобривців насіяла мати У мойм світанковім краю, Та й навчила веснянки співати Про квітучу надію свою. Як на ті чорнобривці погляну, Бачу матір стареньку, Бачу руки твої, моя мамо, Твою ласку я чую, рідненька (М. Сингаївський «Чорнобривці»); Росте черешня в мами на городi, Стара-стара, а кожен рік извіте, Щоліта дітям ягодами годить, Хоча вони не дякують за те. <... Живе старенька мати у господі, Невтомні руки, серце золоте. Щодня і дітям, і онукам годить, Хоч рідко хто з них дякує за те (М. Луків «Росте черешня в мами на городі...»). Поетичний прийом, грунтований на однаковій синтаксичній та інтонаційній побудові, аналогії, подібності, спільності характерних рис, забезпечує ритмомелодику віршів (пор.: стара-стара черешня росте на городі $\mathrm{i}$ старенька мати живе у господi, де суфікс -еньк маніфестує новий план вираження, що сприяє появі нових семантичних відтінків, виникненню позитивно оцінних конотацій). Черешня, вишня, яблуня, верба, тополя тощо часто набувають символічного значення, їхні образи використовуються для створення довершеного художнього образу матері, а тому в поєднанні 3 атрибутивним поширювачем стара такі фітоніми можуть містити непряму вказівку й на материнський вік: Нехай мені судилося блукати у пошуках щасливої зорі - не завагаюсь, як покличе мати додому повернутися з доріг. Зберуся вмить і за світи поїду, та рідній неньці серце привезу! Візьму усе, лише покину біди, щоб радісною бачити сльозу. Ще того ж дня бродитиму полями, провідаю уже стару вербу. I як усіх, то $і$ мене так само питатимуть: де ти так довго був? А ввечері зійде зоря над гаєм, мов 
скаже: де ж носив тебе лихий? I тільки мати промовчить, бо знає, які важкі були мої иляхи (В. Герасимчук «І тільки мати промовчить».

$\mathrm{У}$ словах із частиномовним значенням процесуальності на зразок старіти, постаріти, дериваційною базою для яких послужив відповідний прикметник, актуалізується сема «змінюватися» (з часом, з роками і т. ін.): Мамине обличчя у дитинство кличе, Із дитинства в юність поглядом веде... Мамине обличч сония мені зичить, Мамине обличчя любе й молоде... $\underline{\mathrm{He}}$ старійте, мамо! - б'ю я телеграму, - Не ховайте в змориках тіні від років, А огляньтесь в юність і пройдіть літами - Світлі ваші роки, світлі і гіркі... (М. Дмитренко «Мамине обличчя у дитинство кличе») (пор.: старіти «ставати старим», старий - «який прожив багато років, який досяг старості», старість - «період життя, що наступає після зрілості i характеризується поступовим фізіологічними змінами організму»). Такі фізіологічні зміни можуть сприйматися й візуально, стосуються найчастіше кольору волосся і рис обличчя. У такому разі в межах поетичних контекстів актуалізуються лексеми волосся - коси, обличчя - зморики, що набувають увиразнення за рахунок різних поширювачів або внаслідок використання парафраз: про волосся матері, яке з роками втратило своє забарвлення, говорять, здебільшого послуговуючись чи то словами 3 атрибутивним значенням сиве, біле, сріблисте, чи то лексемою сивина, як-от: Кожен ранок в Тетерів спадають Голубі тумани навесні. I вітри летючі овівають Твої коси в срібній сивині (О. Мусієнко «Матері»); 3-під хустини в неї Світло сивини, Швидко розлетілись Доньки і сини, I нема любові Більшої нема, Ніж ота, щуо серие Мамине трима. Материнська доля Складена з надій. Скрізь вона ясниться В доброті своїи. I немає правди Вищої ніде, Ніж ота, щчо маму По землі веде (В. Крищенко «Пробач нам, мамо»); Матері не вмирають. Умирають сини. Блиск останній для нас- то блиск сивини, I остання зоря, щуо зайде в небеса, Материнська сльоза, болюча сльоза... (Р. Лубківський «Матері не вмирають»). У такий спосіб вербалізується не лише «генетична пам'ять поколінь», а й індивідуальний життєвий досвід того чи того митця. Унаслідок різних метафоричних перетворень, так би мовити, збільшується набір когнітивних ознак, що виокремлюються внаслідок візуального сприйняття: То дарма, щзо йде до тебе осінь, - Ще тобі, матусю, не старіти. Це ж у тебе, певно, на волоссі Павутиння бабиного літа ...(В. Колодій «Матері»). Пор.: на волоссі сивина = на волоссі павутиння бабиного літа (бабине літо - «погідні, теплі дні на початку осені; павутиння, що літає в цей період»); з одного боку, образна уява митця сприймає сивину на маминому волосі як тонесенькі ниточки павутини, що літають у період погідних, теплих днів на початку осені, з іншого, - він і справді нібито намагається переконати і себе, і нас у тому, що це ще не сивина, а оте справжне бабине літо, яке ненароком зачепилося за мамине волосся, адже боляче змиритися $з$ думкою, що в життя кожної 3 матерів ๑ ж. В. Колоїз, 2013. 
приходить «осінь», за якою обов’язково настане «зима».

Концептуальна картина письменницького світу маніфестує й знання, отримані людиною внаслідок зіставлення, порівняння, зокрема із зоонімами (діти - пташенята, мати - пташка - сива / біла пташка (голубка, горлиця, зигзиця і т. ін.), наприклад: Вона давно вже постаріла, Лиш фото діток на стіні, Сидить, немов голубка біла, Одна при пізньому вогні. І їй не спиться, не лежсться, А ти їи вісточку подай, Вона пречиста голубиця, I ти ї̈ не забувай (Л. Забашта «Сдина»); Мамо - віку ти мій, Сива птиче зозуле, Не зозуль, прочини у світанок вікно. Пережиті жалі ловлять літо заснуле, Пада листя з тополь, як в німому кіно. Тріпотить серед поля кофтина в горошок, Дріботить через гони дощинок горох. Із легеньких твоїх павутиночок-змориок Можна виткати смуток на кілька епох (П. Засенко «Мамо - віку ти мій»). В останньому контексті наявна і інший візуальний чуттєвий образ, що демонструє вікові особливості. Він представлений лексемою зморика, уведеною у структуру апозитивного словосполучення павутиночки-зморики (пор.: на волоссі павутиння бабиного літа) й конкретизованою атрибутивним поширювачем легенькі.

Слова на зразок легенькі, павутиночки викликають приємні відчуття, дають змогу адекватно сприйняти неминучий фізіологічний процес старіння, на якому в реальному житті без потреби зазвичай не акцентують (пор.: зморика - «невелике довгасте заглиблення чи борозенка, складка на шкірі обличчя»). Тому лексема зморика частіше супроводжується атрибутивними поширювачами, що мають позитивно оцінну семантику, рідше - навпаки. Наприклад: Я твій портрет фіалками вберу - ти ж так любила голубі фіалки. Мене ти вчила правді і добру, мене до працуі ти привчала змалку... Я доторкнуся до твого чола, на ньому зморики - й ті такі ласкаві... (В. Підпалий «Матері»); У мами взяв літак високий легенькі руки - задля крил. Струмок взяв голос материнський, а клопоти - мала бджсла, а хліб русявий на икуринку взяв теплі зморики із чола (В. Затуливітер «Нічна незряча телеграма»); Та чомусь вона була сумною і сльоза котилася 3-під вій. Зморики злі торкаючи рукою, Світозарик усміхався їй (В. Сосюра «Не одкриє мати карі очі...»); Кожна моя дорога - зморика нова у нені, кожна моя тривога - пасемще сиве у неї. Руки ласкаві изілюю. Скільки з них випито сили: жсали вони і косили, прали і тісто місили...(В. Коломієць «Кожна моя дорога»). В останніх проілюстрованих контекстах репрезентовані знання, отримані внаслідок різних відчуттів, скажімо, тактильних та аудіальних (легенькі руки + материнський голос + теплі зморики), візуальних i тактильних (нова зморика + сиве пасемще + ласкаві руки, де ласкавий «приємний для сприйняття (передусім зором і дотиком - Ж. К.); ніжний»). Відповідно, епітетні слова на зразок ласкавий, ніжний, лагідний, легенький, теплий чи похідні від них - ласкаво, ніжно, лагідно, легенько, те́пло (а іноді й тепло́) - актуалізуються досить часто: В хаті спокійно й затишно. Вечір 
заходить в сім'ю. Мати задумливо й ніжно Гладить голівку мою. Мамо, чого зажурились? Дайте тепло ваших рук. В хаті на згадку лишились Болі й тривоги розлук (Д. Луценко «Хата моя, біла хата»); Вороним конем Схиливсь до мене вечір I поклав до ніг Сідло молодика. Я дивлюсь $і$ чую, Як мені на плечі Лагідно лягає мамина рука. <..> На своїм віку Я бачив рук немало, Добре знаю теж У недруга яка, Та коли я падав, Завжди піднімала Трепетна $i$ ніжна мамина рука (М. Ткач «Мамині руки»). Трапляються ситуації, у яких вербалізуються знання, отримані внаслідок не лише зовнішніх, але i внутрішніх відчуттів, маніфестуються звичайно лексемами душа і серие, як-от: Немає вроди над калину, - Вродливіша лиш за калину Моя кохана. Троянда в світі найніжніша, - Лише ніжніша від троянди Душа матусі (М. Дмитренко «Мамине обличчя»); В місячнім німбі волосся, Як у прощальнім вінку. Скільки ж біди довелося їи пережить на віку? Як вона бідна старалась В клопотах хатніх щуодня, А підступилася старість - I залишилась одна. Де ви, краї мої листяні? За перевалами літ. Я відчуваю й на відстані, Як в неї серие болить. Шлях свій позначу томами. Все Україні віддам. Тільки покинута мама - Докір душі і очам (А. Михайлевський «Покинута мати»).

Поетичний образ матері грунтується на історичному, соціокультурному і великою мірою на біографічному тлі кожного з авторів. У його змалюванні переважають чомусь мінорні, сумні, журливі риси: лише на відстані перейдених років, особливо народивши своїх дітей, людина глибоко осмислює, а то й переосмислює своє ставлення до тієї, єдиної і рідної, яка дала життя: Принесу в подарунок мрію, Що перлинами виграє. Тільки зараз я розумію Материнське серче твоє. Прислухаюся і учуся Усьому, що порадиш ти. Мила, рідна моя матусю, Як до мудрості важко йти. Скільки бур, і вагань, $і$ злетів На дорозі нелегкій тій... Не зустрінеш всього в поетів, Не побачиш у барвах мрій. Тільки ти, єдина, розкажеш, Як уміють лиш матері. I заснути пізніше ляжеш, I піднімешся до зорі. Скільки світла у слові «мати»! ... Чую: донька мене гука, Поспімаю ї̈ обняти, I тривожно тремтить рука. Незабутими диво-снами Знов дитинство моє встає... Лиш тепер зрозуміла, мамо, Я велике серие твоє (Л. Клименко «Моїй матусі»).

Когнітивні ознаки одоративних чуттєвих образів (пор.: потенційними стимулами нюхової системи $є$ випари або речовини, що легко випаровуються, - одоранти (лат. odorans - пахучість) пов'язуються передусім із лексемами запах і пахнути.

Одоративна образна складова концепту МАТИ інтерпретується знайомими $з$ дитинства запахами рослин, що в українській лінгвокультурі отримують особливе смислове наповнення, набувають символічного значення: Запахнув чебрець 3 материнського поля, Немов нагадати силкується він, Що мати дала нам і сонце, і долю, Дала, не забравши нічого взамін (В. Крищенко «Де мати посіє...»); Хата моя, біла хата, ๑ ж. В. Колоїз, 2013. 
Рідна моя сторона. Пахне любисток $і$ м'ята, Мальви цвітуть край вікна (Д. Луценко «Хата моя, біла хата»); $A$ бува ж - перелітне птаство збереться: неприкаяні... дух - євшаном пропах... Неня шанує від серия, усіх жаліє, і тремтливинка на губах винувато тепліє... По ї̈ молитві біди не станеться. Тільки чим віддячить - за біль!.. Чорнобривцями гірко пропахли станції. Хмаровінь... Голубінь... (В. Коломієць «Кожна моя дорога»); Чорна смородина. Мальви. Глід над землею горить. Мною покинута мама Довго стоїть край воріт. Віє туманами з лугу. Пахне барвінком нічним. Шкода, що я ї̈ тугу Вже не розраджу нічим (А. Михайлевський «Покинута мати»). Фітоніми чебрець, любисток, м'ята, чорнобривці, барвінок і т. ін. виступають символами пам'яті про дитинство, матір, батьківщину, актуалізовані про них знання, з одного боку, викликають почуття смутку, а з іншого, - додають життєвих сил. Запах чебрецю, любистку, м’яти тощо - це «запах» матері, який ініціюється уявою того чи того індивіда. Мати «пропахла» плодами землі (пор.: міфологічний образ матері-землі), водночас наділивши цю землю своїм запахом: Бути зими охоронцем Холод вже більше не міг - I, опромінений сонцем, Плавиться сірий сніг. Стала рілля у полі Схожа на крила бусла. Мліють дерева голі Од лоскотунків тепла. Птаства весільні перезви Поміж верхів'ями чуть, А біловиді берези Кров свою людям здають...Скоро під небом високим Маревом степ задимить I ластівки чорним шовком Мережити будуть блакить. Будуть квіток метелики Пурхати в літа ногах, I табунами веселки Попаски йтимуть в лугах... Тягнеться зеленруками Юнь з-під старої трави... Мамо, тут все дише Вами, А тільки, мамо,де ж Ви? Сонще весні знов привітно Свят-рушнички вистеля, I так знайомо, так рідно Мамою пахне рілля... (Д. Іванов «Провесняна балада»).

3-поміж аудіальних чуттєвих образів вирізняються ті, до яких належать відчуття звуку і тонів - висоти, сили (гучності), тембру. За твердженням науковців, немовля здатне розпізнавати свою матір як за запахом, так і за голосом. Тому голосу, поряд із візуальними характеристиками, у створенні художнього образу матері відводиться значна роль. Лексема голос уводиться у структуру художнього тексту разом із означальними поширювачами материнський (мамин), подекуди увиразнюється чи то узуальними епітетами, як-от: тихий (тихо), ніжний (ніжно), дзвінкий (дзвінко) і т. ін.: Мама сьогодні співала, Майже так, як і колись. Знову несла воду Галя, В гості Іванко просивсь. Я пам'ятаю, як дзвінко Голос у мами звучав... Тільки змінився із віком, В себе впустивши печаль. Тільки у ньому почулись Ноти занадто гіркі... Тиха молитва про чуйність Вже в перезрілі роки (О. Менський «Мама співала»), чи то індивідуально-авторськими, або оказіональними, на зразок: Цієї ночі в місячнім саду Червоно-чорні рожі - як стигмати. I безшелесну я почув ходу - То надійшла моя покійна мати. I голосом ясної тишини Вона сказала: - Схаменися, сину, 
Звільнися од солодкої мани, Яка тебе провадить до загину. Ти взяв ї̈, як хрест на рамена, І думаєш, щуо це тобі під силу. Не білий парус у житті вона, А чорний камінь на мою могилу... Щось доторкнулось до мого чола У нереальну місячну годину, Незрима постать тихо відійшла, Лише здаля почулось: - Сину, сину!.. Я не послухав (І. Качуровський «Цієї ночі в місячнім саду»).

Унаслідок метонімічного переосмислення аудіальні характеристики можуть стосуватися не лише голосу як «сукупності різних щодо висоти, сили i тембру звуків, які видає людина за допомогою голосового апарата», а й самої людини. У такому разі атрибутивний поширювач супроводжує саму лексему мати: $А$, серце, серие, клич в дорогу, В той край, де літечко сяйне, Де шепче явір коло двору I тиха матір жде мене (А. Демиденко «Найзаповітніша любов») (пор.: тиха матір - «безмовна, сумна») або абстрактний іменник, що демонструє іiі стан, настрій, риси характеру: Випала дітям доба пожежна, гойдає мене земля. Тиха жура й доброта безмежна - мати моя. Думо вечірня, думо світанна!.. Печаль ластовина, печаль золота. В пісні - любов і прощання за всі літа, за всі літа... (В. Коломієць «Кожна моя дорога»).

Знання, грунтовані на аудіальних відчуттях, актуалізуються й за допомогою інших лексем, семантичне наповнення яких передбачає, так би мовити, «звукове вираження». До таких належать насамперед дісслова говорити, казати, озиватися і т. ін.: Усі мовчіть - щось мати каже, Цвітуть притишено слова. Вони із веселкових вражень, 3 любові, що в душі жива. Зійилися діти всі до хати, Де хліб, як доля, на столі... Усі мовчіть: говорить мати Вустами неба $i$ землі (В. Крищенко «Говорить мати»).

Аудіальна складова концепту МАТИ репрезентується також лексемами слово, пісня, мова. Материнське слово (пісня, мова) - це рідне слово, а рідне слово - це не просто засіб людського спілкування, а та коштовна річ, подарована при народженні матір'ю, утрата якої призводить до великої біди, нещастя, поневіряння. Залишитися без слова, рідного слова, утратити його це все одно, що залишитися без матері, утратити іiі у прямому й переносному значенні: Притих соловейко, Схилилась калина. Замовкла хатина Без маминих слів. Кому ж розказати, До кого озватись, 3 ким тишком поплакати Про болі й жалі? На кожному крочі I в кожному рочі Зі мною ти, мамо, Голубко моя! Журбою-вербою Озвися весною, I чарами м'яти У літо прийди (І. Бондарчук «Пам’яті матері»).

Унаслідок метафоризації в поетичних текстах з'являються нові семантичні обертони, що дає підстави говорити про розширення концептуально-смислового поля, появу нових асоціативних зв'язків, іноді несподіваних і непередбачуваних. Наприклад: Молюся Вам за пісню колискову, За ласку, карий погляд і терпець, За усмішку Богині сонейкову Й за те, що я молюсь, молюсь тепер... О Мамо-ненько, извіте яблуневий, ๑ ж. В. Колоїз, 2013. 
Не збитий громом долі і весни, Я Вам готовий прихилити небо, Щасливі й світлі насилати сни. Та Ви мені шепочете: "Спасибі. Онукам, сину, небо прихиляй, А щире материнське диво-сниво Не переводь на щзастя, не збавляй. Бо сни мої - одвічна туга й мука, Турбота про дітей, про родовід, Щоб мали ви любов і щоб розлука Не засліпила серче вам і світ». Молюся Вашій мудрості, Матусю, Ясного слова чистій простоті, До нього я душею притулюся - До скарбу найдорожчого в житті. Бо в нім любов $і$ дім, і подзвін жита, Криничя пам'яті і віри джерело. Бо в нім моєї совісті молитва, Ріка моя, і човен, $і$ весло... Молюся Вам, єдиний Боже, - Мамо. Молюся, та нічого не молю: Ні харчу, срібла-злата, ані краму... Живіть лишень! Благаю $і$ велю! Бо Ви ж, Матусю, - мова Украӥни, Бо Ви ж, Матусю, - доля трудова, Бо Ви - натхненна пісня солов їна, Душа народу рідного жива. Молюся Вам, єдиний Боже, Мамо...(М. Дмитренко «Синівська молитва»).

Проілюстрований контекст переконливо засвідчує здатність концепту МАТИ вступати в різні асоціативні зв'язки, створювати асоціативні ряди й навіть поля: МАТИ - БАТЬКІВЩИНА; МАТИ - РІДНА ЗЕМЛЯ; МАТИ РІДНА МОВА (РІДНЕ СЛОВО); МАТИ - ПІСНЯ (КОЛИСКОВА ПІСНЯ), що демонструють розгалуженість смислових зон, у яких відбувається асоціювання: МАТИ - БАТЬКІВЩИНА - УКРАЇНА - РІДНА ЗЕМЛЯ НАРОД - ПАМ'ЯТЬ - ВІРА - СОВІСТЬ - ДІМ - РІЧКА - ЧОВЕН $B E C Л O$ і т. ін. Поетичне мовомислення репрезентує досліджуваний концепт у різних художньо-семантичних площинах. Пор. також: На розгінних вітрах Неспокійного світу Хай несе нас вперед Весняна течія, Як надійний маяк Серие мамине світить, I злітає із вуст: Мамо, мамо моя... Образ твій обійма Рідну землю і небо, Колоситься навкруг У липневих житах. Ми у снах молодих Прилітаєм до тебе, Щоб набрати снаги На добро, на життя. Нам озвучився день 3 материнської мови, Нам розвиднився він Із iї доброти. Материнську печаль, Що гірчить полиново, Материнську сльозу - Ти собі не прости (В. Крищенко «Ти собі не прости») (МАТИРІДНА ЗЕМЛЯ - НЕБО - ЖИТО - ДОБРО - ЖИТТЯ - МАТЕРИНСЬКА $M O B A)$. Образна взаємодія, текстуальна поетика, асоціативна ускладненість сприяють тому, що звичайні слова набувають естетичної сили. Потужним естетичним потенціалом вирізняються ті поетичні тексти, у яких наявні так звані національні маркери, зазвичай це топонімічні (але не тільки!) назви: Спи, моя дитино золота, Спи, моя тривого кароока. В теплих снах ідуть в поля жста, I зоря над ними йде висока. Спи, моя гіллячко голуба, Тихо в мойм серчі і щуасливо. За вікном хлюпочеться плавба Твоӥх літ і долі гомінливої. Спи, моя дитинко, на порі. Тіні сплять і сонна яворина... Та як небо в нашому Дніпрі, Так в тобі не спить хай Украйна. Хай вона не спить в тобі повік, Бо вона - для тебе $і$ для світу... Люлі, мій маленький чоловік, Капле сон сріблястий з верховіту... (М. Вінграновський «Перша колискова»); 
Ти уміла ходить лиш босоніж по рідній землі, По стежках-моріжках $i$ порепаній чорній ріллі, По лугах дніпрових, де трава до плечей дістає, Де промчалось колись босоноге дитинство твоє. Ти ростила синів $і$ їм пісню y серие дала, I в одного із них самоцвітом вона зацвіла. Тебе Київ прийняв, наче матір шановну свою, Що і слово, $і$ спів ще з дитинства дала солов'ю. Лиш на день до синка, а душа уже рветься туди, Де шумлять пшениці і куди ще не йдуть поїзд, Де немарно колись ти купала в любистку синів I звучав по ночах украӥнської матері спів. Ти босоніж ідеш по міському камінню одна, Пустотливий вітрець твій розиитий рукав напина. I питають ијкаві: - Чом, бабусю, ви боса йдете? I великая мати їм суворо говорить на те: - Я босоніж іду, щзоб изю землю завжди відчувать, Щоб за неї боліть, $i$ боротись до смерті, й страждать. Я босоніж іду, щоб землі дорогої тепло, Наче струмінь палкий, прямо в серие до мене текло, Щоб довіку мене зігрівало святе відчуття, Що лиш рідна земля може дати нам силу життя (Л. Забашта «Матері поета»). У подібних контекстах концепт МАТИ демонструє етнічну складову (явір, Дніпро, Украӥна, Київ, розшитий рукав і т. ін.), усвідомлюється як УКРАЇНСБКА МАТИ. Цьому сприяють і спродуковані в різний спосіб атрибутивні словосполучення, у яких саме означення вказує на територіальну, етнічну, національну належність: Чи Галицька вона, а чи Луганська? Донеиька, може?! Слобожанська теж! Чи Київська - Сарматська $i$ Поганська Повстала з дна і клекоту пожеж? В лісах Волинських, в схронах Тернопілля Ось так сказала: вийди і бери 3 Дністра й Нічлави потойбічне зілля I напувай охлялі прапори! Дивись на зорі - не здавайся зморі. Де клекіт мук, там і любов до дна. Молись на Матір. В неї очі хворі. Вона сидить самотня край вікна. I дожидає, дожидає зміни Крізь кляту кукурудзяну судьбу, I дожидає тої Украӥни... Десь Син пішов. На хрест? Чи на ганьбу?! Десь Син пішов. Вона чекає Сина. Крізь сторч століть - все та ж самотина, Їй вибирає очі хуртовина У кожній хаті $з$ кожного вікна... (І. Драч «Наша мати»).

На окрему увагу заслуговує семантичне наповнення МАТИ - XАTA, що виникає внаслідок ускладнення асоціативних зв'язків МАТИ БАТЬКІВЩИНА - РІДНА ЗЕМЛЯ. Як відомо, у світовій символіці житло символізує жіночий аспект світостворення, а також сховище мудрості, традиції, життя. В українській лінгвокультурі споконвіку хата виконувала своє природне призначення родинного вогнища, де народжувалися, оберігалися кращі сімейні традиції, які згодом переходили у спадок дітям: любов до батьків, природи, пісні, до праці. Хата в українців завжди асоціюється 3 чимось світлим, тому, згідно з давньою традицією, їх вибілювали, надавали їм святкового вигляду, особливо навесні перед Великоднем: Побіліть, мамо, хату - по-весняному чисто, Щоб іздалеку бачив: як лебеді - стіни. Побіліть, мамо, хату - сад одягне намисто, Зачвіте березнево, замумить ๑ ж. В. Колоїз, 2013. 
безневинно. Хай забудуться болі, як зійде сніг торішній, Хай цвітуть кругом хати світло-райдужні квіти... Скоро синім тополям небо листя розвіша - Побіліть, мамо, хату по-весняному чисто (Г. Іваненко «Веснянка для матері») (пор.: МАТИ - РІДНА БІЛА ХАТА - БІЛА ЛЕБІДКА).

Цілком закономірним $є$ i те, що в поетичних текстах лексема хата увиразнюється атрибутивними поширювачами на зразок рідна, батьківська, отча, мамина і т. ін. Наприклад: Валили хлів старий із братом, А поруч свідок боязкий: Лебідка біла, рідна хата... Який же вік ї̈, який? (М. Дмитренко «Валили хлів старий із братом»); До отчої, До маминої хати На стежиі - хай не виросте трава... Є станція. Нас тут чекає мати. Не забувайте... Мати ще жива...(Д. Кремінь «Станція імені матері»).

Унаслідок деталізації може модифікуватися план вираження (пор.: наприклад, ХАТА - iї складові (ПОРІГ, ВІКНО, СТІНИ і т. ін.; ХАТА ОБІЙСТЯ; ХАТА - РОДИННЕ ГНІЗДО тощо). Оригінальність образів зумовлюється асоціативними зв'язками, сформованими в лінгвоментальній сфері письменника: Злітались ми в хату до мами Зігрітись в родиннім гнізді. Самі вже ставали батьками, Та мов до живої води Тягло нас додому, до мами, У край лепехи й лободи. Брати мої часу морями Спливли у човнах домовин... До нашого двору, до мами, Уже поспішаю один. Біжать осокори рядами Обабіч дороги в село, А сонечко з ласкою мами Дарує осінне тепло. Село задиміло димами - Повсюди димлять димарі, У хатах таких, як $і$ в мами, Пильнують вогонь матері. Село задиміло димами - Стовпи піднялися до хмар... I тільки над хатою мами Не дихає в небо димар. Стою в самоті коло брами, Шукаю очима в вікні Лице незабутньої мами, Що бачу так часто вві сні. На таночку брязну ключами, У двері зайду тихкома... Повіяло смутком, бо мами У маминій хаті нема. Немає ї̈ й за полями - Згубилися 6 росах сліди... Я ж їхати буду до мами, Як завжди було, як завжди. В леваді верба під вітрами У мене про неї пита... I холодно в світі без мами, Хоч сонце теплом огорта. Немає ї̈ й за горами, Та думка святиться одна: Якщо поспішаю до мами, То, певно, є в світі вона (П. Засенко «На свято до мами»); Та ж сама стежка, і дерева ті, I ті ж поля, і хати при дорозі, Лиш ворон у тривожній чорноті, Немов чаклун на отчому порозі, Роковано черкнув своїм крилом I шугонув із двору чорним шумом. I стала чорна хмара над селом, I білий день вгорнувся чорним сумом. Померла мати - от і всі слова (Л. Білаш «Матері»).

У поетичному мовленні концепт МАТИ потрактовується й крізь призму міфологічних уявлень і християнських традицій, викликає асоціації на зразок МАТИ - БЕРЕГИНЯ; МАТИ - СВЯТА; МАТИ - ПРЕЧИСТА; МАТИ - БОГОРОДИЦЯ; МАТИ - МАДОННА; МАТИ - СТРАДНИЦЯ і т. ін. Наприклад: Думо вечірня, думо світанна!.. Печаль ластовина, печаль золота. В пісні - любов і прощання за всі літа, за всі літа... I тополею видиться в полі, й берегинею в хаті. Проти недолі, проти сваволі - 
українська матір! (В. Коломієць «Кожна моя дорога»). У міфології, як відомо, берегиня - захисниця людей від усякого зла, добра «хатня» богиня, що оберігала оселю, малих дітей, добробут сім’ї не лише за життя, а й після смерті (пор.: існує думка, згідно з якою схематичне зображення берегиніжінка 3 піднесеними для благословення руками - трансформувалося в малюнок тризуба). Її переосмислений художній образ, очевидно, представлений у таких поетичних рядках: Вона посміхнулась, красива $і$ сива, як доля, Махнула рукою - злетіли увись рушники. «Лишайтесь щзасливі», - $i$ стала замисленим полем На цүілу планету, на всі покоління й віки (Б. Олійник «Пісня про матір»), де, відходячи «за межу», матір востаннє «благословляє» своїх дітей та онуків, бажає їм щасливої долі. Мати стає тим «місточком», тими «сходинками», які 3'єднують невидиме «вишнє» небо i наш видимий «дольний» світ. Лінгвоментальному осмисленню концепту сприяє й наявність лексеми рушники, що сприяє розгалуженню асоціативних зв'язків: МАТИ - БЕРЕГИНЯ - ХАТА - РУШНИК.

Для української лінгвоспільноти рушник є своєрідним оберегом, символом не лише щасливої долі, любові, краси, незрадливості, надії, побажання добра, але й прощання. Вишитий рушник - це та «ниточка», яка поєднує покоління, він упродовж тисячоліть залишається одним із основних «хатніх» атрибутів. Хата, рушник (як, до речі, i сорочка) вербалізують національну складову концепту МАТИ, асоціюється 3 чимось світлим, чистим, тому подекуди й супроводжуються відповідними епітетами: Цілує соние рушники У чистій материній хаті. І чути, як мої думки, Мов ластівки, стають крилаті (М. Сингаївський «Цілує сонце рушники...»); Літа, неначе птахи, пролітали. Матусі коси дивом зацвіли. І я сорочку білу вишиваю, Як вишивала матінка мені. Виконуй доню - мама говорила - Життя закони, істини прості. Не зраджуй землю, щуо тебе зростила. Не залишай нікого у біді (Н. Май «Мамина сорочка»).

Письменницький концептуальний світ репрезентує нові знання, грунтовані на вдумливому підході того чи того автора до слова, на майстерному використанні різних художніх засобів і можливостей загальнонародної мови: Уночі мені приснилась мати, I до ранку я заснуть не міг. Яблуня ввижалась коло хати, незабутній батьківський поріг. Крізь иляхи пекельної розлуки, довгі $i$ натруджені літа мати простяга зашерхлі руки, знову нас до серчяя пригорта. Розлетілись $i$ сини, i дочки по світах, мов сизі голуби. Тоскно з полотняної сорочки проглядає заполоч журби. А вона вечірньою порою йде у сподіваннях до воріт. Може, й діти вже не за горою душу поспішають їи зігріть. Гомонять сполохані тополі, я, мов птах, до матері лечу. Всі ї̈ невиплакані болі вогняною спрагою печуть. A дорога стелиться, як лиштва, небо тріпотить в моӥх очах. Жайвори далекого дитинства линуть 3 материнського плеча (Д. Луценко «Синівська пісня»).

() Ж. В. Колоїз, 2013. 
3 прийняттям та поширенням християнства міфологічний образ матері-берегині трансформується в образ Богоматері (Богородиці), яка попри велику материнську любов віддає людству найдорожче, що в неї $є-$ свою дитину: Спішили верхи. Їхали возами. Похід розтягся на дванадиять верст. I Божа Мати плакала сльозами - та поможіть нести ж йому той хрест! Чи ви не люди?! Що за чудасія, дають стариям, підсаджують калік. А тут же йде, ну, добре, не Месія, - людина просто, просто чоловік! (Л. Костенко «Шлях на Голгофу»). Такий емоційний стан Богоматері свідчить: материнська любов - почуття глибоке і безмежне. Будучи не в змозі відвернути «чашу цю», Божа Мати не залишає свою дитину напризволяще, без допомоги, без моральної підтримки. Символічним став і образ Богоматері 3 немовлям на руках, що «втечею» намагається врятувати життя своїй дитині: Скорботна мати ішла поволі, Туди, де зріло колосся в полі. Несла на грудях дитя, мов птаху, Не стало сили, лягла край шляху. Мов стебла руки син простягає, I хліба в мами усе благає, Але благання свого пташати, Уже не чує стражденна мати (В. Забаштанський «Стражденна мати»). Його індивідуально-авторська інтерпретація безпосередньо залежить від світоглядних орієнтирів письменника, його конфесійної належності.

Лінгвоментально осмислюється концепт МАТИ в семантичному наповненні МАДОННА (матір Ісуса Христа для католиків). Мадонна 3 немовлям на руках стала уособленням чистої, ніжної жінки, люблячої матері. Для багатьох українців мадонна асоціюється з Шевченковою Катериною (МАТИ - МАДОННА - ШЕВЧЕНКОВА КАТЕРИНА). Наприклад: Доки буде жити Украӥна В теплім хлібі, в барвних снах дітей білим полем Катерина 3 немовлям, притнутим до грудей. Освятивши невимовним болем Все прийдешнє, кожну нашу мить, Йде вона, $i$, мов велике коло, Біле небо навздогін летить. Про дівочу циноту, про калину Не співай, поете, не квили, Бо іде сьогодні Катерина Тим шляхом, що наші кревні йшли. Вилами розхитували трони, Руйнували все старе дотла, Тільки би Шевченкова Мадонна В сніжне небуття не полягла! Тільки би вона донесла сина До свого народу, до людей. Біле поле. Біла Катерина 3 немовлям, притнутим до грудей (Л. Кисельов «Катерина»). Смислова парадигма увиразнюється, асоціативні зв'язки розширюються: МАТИ ІСТОРІЯ, МАТИ - НАРОД, МАТИ - ВІЧНІСТЬ.

Крім того, зауважимо, художній образ материнського безсмертя непоодинокий у поетичних творах, на що вказують передусім атрибутивні поширювачі на зразок вічна, безсмертна: Нічна незряча телеграма не висадить вікна мого: безсмерта, вічна в мене мама - як хліб, як поле, як $\underline{\text { вогонь }}$ (В. Затуливітер «Нічна незряча телеграма»). Щоправда, як і в кожної живої істоти, біологічне існування матерів обмежене. Тому частотною $є$ вербалізація стану МАТИ - ПОМЕРЛА: Померла мати - тут не до сльози. Померла мати - навіть не до крику! Якої жені вимолить грози, Щоб 
розбудить ї̈, малесеньку й велику?! Піду до сония - з ним вона вставала, У полі разом з ним росу пила. Його проміння в житній сніп ховала, Мене його промінням сповила. Та коли й сонце вже не допоможе - Життя земного вічне джерело, - Я місячя $і$ зорі розтривожу, Схилю в мольбі своє сумне чоло: Нехай ї̈ до себе заберуть, Раптово обернувши дивним птахом, Щоб завше їи стелилась тиха путь Під зоряним Чумацьким вічним Шляхом (Л. Білаш «Матері»); Перед смертю хотіла мати Щось важливе мені сказати. Я далеко від неї був - Слів останніх ї̈ не чув. І гризе мене каяття, Що за довге своє життя За турботами та ділами Мало я прислухавсь до мами. I ніколи не буду знати, Що мені не сказала мати (М. Луків «Перед смертю хотіла мати...»). Причому саме слово з відповідною семантикою (померти, смерть) може бути й відсутнім у структурі поетичного тексту. У такому разі використовуються парафрастичні звороти: День відболів. Ніч віджурилася. Думка на думку, Як дошка, лягла: Я ж на вас, мамо, Не надивилася! Я ж вам так мало В житті помогла! Вік проминув. Я вам відснилася. Небо сирітське, Як віко труни: Стежка додому В травах згубилася, В кожної квітки Погляд сумний. Літо минуло. Осінь спинилася. Страшно подумати: Буде зима! Я ж на вас, мамо, Ще не молилася, А вже молитва - Німа... (Г. Чубач «Німа молитва»); На човнику згадок мені веслувати У морі нічному печалі. Все далі відходять і батько, $і$ мати. Все далі. Розтали в минулім, як берег далекий Осінньої ночі. Не стало. Полинули в ірій два сивих лелеки, Все далі. На човнику згадок мені веслувати У морі нічному печалі. 3 роками до мене $і$ батько, і мати Все ближче - $i$ далі. I хоч навкруги ще у розпалі літо - Призахідне сонце все нижче. До тих, хто за обрієм, з кожною миттю Все далі - $i$ ближче (Д. Кулиняк «Все далі»).

Художньо-семантичне наповнення концепту МАТИ не вичерпується окресленими смисловими парадигмами. Його інтерпретація у віршованих текстах $є$ багатоаспектною. Ми акцентували передусім на ядерній його частині, принагідно залучивши до аналізу й деякі периферійні. Поза увагою залишилися такі художньо-семантичні площини, як МАТИ - НАЙВИЩА ЦІННІСТЬ - ЛЮБОВ - ДОБРО - ЩАСТЯ - СОВІСТЬ СПРАВЕДЛИВІСТЬ - ТУРБОТА - ПРАЦЬОВИТІСТЬ; МАТИ - СОНЦЕ СВІТЛО - ЗОРЯ; МАТИ - ГОЛУБКА - ГОРЛИЦЯ - ЗИГЗИЦЯ ЖУРАВКА - ЛЕЛЕКА - БДЖОЛА; МАТИ - ТОПОЛЯ - ВЕРБА КАЛИНА - ЯБЛУНЯ - ВИШНЯ - РУТА-М'ЯТА тощо.

Багатовимірно представлені й асоціативні поля, грунтовне осмислення яких неможливе в межах однієї статті. На детальнішу увагу заслуговує й інтерпретація у структурі досліджуваного концепту лінгвоментальних складників. Утім, це проблема подальшої наукової праці, пов'язаної і 3 аналізом вербалізації відповідного концепту в мовній картині світу як способу фіксації національно-культурного світогляду.

Насамкінець зауважимо: концепт МАТИ являє собою своєрідний код, ๑ ж. В. Колоїз, 2013. 
знання якого дасть змогу глибше зрозуміти наші національні культурні цінності, ті життєві установки, орієнтири, моральні ідеали, традиції, що закладаються від народження тією РІДНОЮ, СВІТЛОЮ, СДИНОЮ, НЕЗАБУТНЬОЮ для кожного $з$ нас НЕНЕЮ, НЕНЬКОЮ, МАМОЮ, МАТІР'Ю, МАТУСЕЮ, якій людство має завдячувати своїм існуванням, адже справедливо кажуть: доки є МАТИ, доти триватиме життя на землі.

\section{Література}

1. Голобородько К. Ідіостиль Олександра Олеся : лінгвокогнітивна інтерпретація : [монографія] / К. Голобородько. - Х. : ХІФТ, 2010. - 527 с.

2. Маслова В. А. Лингвокультурология / В. А. Маслова. - М. : Издательский центр «Академия», 2001. - 208 с.

3. Калашник В. С. Мова поезії і картина світу / В. С. Калашник // Людина та образ у світі мови : вибрані статті. - Х. : ХНУ, 2011. - С. 162-167.

4. Карасик В. И. Культурные доминанты в языке / В. И. Карасик // Языковая личность : культурные концепты : сб. науч. тр. - Волгоград -Архангельск, 1996. - С. 3-16.

5. Карасик В. И. Языковой круг : личность, концепты, дискурс / В. И. Карасик. Волгоград : Перемена, 2002. - 477 с.

6. Кубрякова Е. С. Язык и знание / Е. С. Кубрякова. - М. : Языки славянской культуры, 2004. - 271 с.

7. Марфіна Ж. Лексема МАТИ в поетичних контекстах Андрія Малишка Ж. Марфіна : [Електронний ресурс] / Режим доступу : http://kulturamovy.univ.kiev.ua

8. Марфіна Ж. Я все віддам за одне недоспіване «мамо» (міфопоетика словаобразу мати в поезії Б. Олійника) / Ж. Марфіна // Культура слова. - К. : Видавничий дім Дмитра Бураго, 2011. - Вип. 74. - С. 22-28.

9. Приходько А. М. Концепти і концептосистеми в когнітивно-дискурсивній парадигмі лінгвістики / А. М. Приходько. - Запоріжжя : Прем’єр, 2008. - 332 с.

10. Попова 3. Д. Когнитивная лингвистика / 3. Д. Попова, И. А. Стернин. - М. : АСТ : Восток-Запад, 2007. - 314 с.

11. Словник символів / За заг. ред. проф. О. І. Потапенка : [Електронна версія] / Режим доступу : http://ukrlife.org/main/evshan/symbol.htm

12. Степанов Ю. С. Константы : Словарь русской культуры. Опыт исследования / Ю. С. Степанов. - М. : Школа «Языки русской культуры», 1997. - С. 40-76. 